\title{
Quercetin Inhibits Pacemaker Potentials via Nitric Oxide/cGMP-Dependent Activation and TRPM7/ANO1 Channels in Cultured Interstitial Cells of Cajal from Mouse Small Intestine
}

\author{
Huijin Gimª Joo Hyun Namª Soojin Lee ${ }^{\mathrm{a}, \mathrm{b}}$ Ji Hwan Shimª Hyun Jung Kimª,b \\ Ki-Tae Haa,c Byung Joo Kimª, \\ ${ }^{a}$ Healthy Aging Korean Medical Research Center (HAKMRC), bivision of Longevity and Biofunctional \\ Medicine and 'Division of Applied Medicine, Pusan National University School of Korean Medicine, \\ Yangsan, Republic of Korea, ${ }^{\mathrm{d} D e p a r t m e n t}$ of Physiology, Dongguk University College of Medicine, \\ Kyungju, Republic of Korea, ${ }^{e}$ Channelopathy Research Center (CRC), Dongguk University College of \\ Medicine, Goyang, Republic of Korea
}

\section{Key Words}

Interstitial Cells of Cajal • Quercetin • Gastrointestinal tract • TRPM7 channel • ANO1

\begin{abstract}
Background: Quercetin regulates gastrointestinal (GI) motor activity but the molecular mechanism involved has not been determined. The authors investigated the effects of quercetin, a flavonoid present in various foods, on the pacemaker activities of interstitial cells of Cajal (ICCs) in murine small intestine in vitro and on GI motility in vivo. Materials and Methods: Enzymatic digestion was used to dissociate ICCs from mouse small intestines. The whole-cell patch-clamp configuration was used to record pacemaker potentials in cultured ICCs in the absence or presence of quercetin and to record membrane currents of transient receptor potential melastatin (TRPM) 7 or transmembrane protein 16A (Tmem16A, anoctamin1 (ANO1)) overexpressed in human embryonic kidney (HEK) 293 cells. The in vivo effects of quercetin on GI motility were investigated by measuring the intestinal transit rates (ITRs) of Evans blue in normal mice. Results: Quercetin (100-200 $\mu \mathrm{M})$ decreased the amplitudes and frequencies of pacemaker activity in a concentration-dependent manner in current clamp mode, but this action was blocked by naloxone (a pan-opioid receptor antagonist) and by GDP $\beta S$ (a GTP-binding protein inhibitor). However, potassium channels were not involved in
\end{abstract}

H. Gim and J.H. Nam contributed equally to this work and should be considered joint first authors.

Byung Joo Kim

KARGER 125
Division of Longevity and Biofunctional Medicine, Pusan National University School of Korean Medicine, 49 Busandaehakro, Mulqeum-eup, Yangsan Gyeongsangnamdo, 626-870 (Republic of Korea); E-Mail vision@pusan.ac.kr 
these inhibitory effects of quercetin. To study the quercetin signaling pathway, we examined the effects of $1 \mathrm{H}-[1,2,4]$ oxadiazolo[4,3-a]quinoxalin-1-one (ODQ), an inhibitor of guanylate cyclase, and of RP-8-CPT-cGMPS, an inhibitor of protein kinase G (PKG). These inhibitors blocked the inhibitory effects of quercetin on pacemaker activities. Also, L-NAME (100 $\mu \mathrm{M})$, a non-selective NO synthase (NOS) inhibitor, blocked the effects of quercetin on pacemaker activity and quercetin stimulated CGMP production. Furthermore, quercetin inhibited both $\mathrm{Ca}^{2+}$-activated $\mathrm{Cl}^{-}$channels (TMEM16A, ANO1) and TRPM7 channels. In vivo, quercetin (10$100 \mathrm{mg} / \mathrm{kg}$, p.o.) decreased ITRs in normal mice in a dose-dependent manner. Conclusions: Quercetin inhibited ICC pacemaker activities by inhibiting TRPM7 and ANO1 via opioid receptor signaling pathways in cultured murine ICCs. The study shows quercetin attenuates GI tract motility, and suggests quercetin be considered the basis for the development of novel spasmolytic agents for the prevention or alleviation of GI motility dysfunctions.

Copyright $@ 2015$ S. Karger AG, Basel

\section{Introduction}

Quercetin (3,3',4',5,7-pentahydroxyl-flavone) is one of the most common flavonoids and is present in various foods, such as, onions, apples, broccoli, tea, and red wine [1-4]. Quercetin has a variety of activities in man. For example, it has been reported to have antioxidant [5-7], anti-inflammatory [8], anti-anaphylactic [9], anti-aging [10], antiplatelet aggregatory [11], radioprotective [12], immunomodulatory [13], antidiabetic [14], and anticancer [15] effects, and to improve lipid metabolism [16,17] and endurance exercise capacity [18]. Quercetin also reduces gastrointestinal (GI) intestinal transit in mice [19], induces intestinal smooth muscle relaxation [20], and prevents castor oil-induced diarrhea [21]. These properties are consistent with the use of flavonoids as antidiarrheal drugs in traditional medicine. However, the cellular and molecular mechanisms underlying the GI motility effects of quercetin are not well understood.

Interstitial cells of Cajal (ICCs) are the GI pacemaker cells that generate rhythmic oscillations in membrane potentials known as slow waves [22, 23], and ICC loss has been implicated in several motility disorders, which suggests that they play an important role in the regulation of GI motility [24]. In addition, ICCs mediate inhibitory and excitatory signals from the enteric nervous system to smooth muscle [25-27], and evidence indicates that endogenous agents, such as, neurotransmitters, hormones, and paracrine substances, modulate GI tract motility by influencing ICCs [28-31]. Furthermore, it has been shown that the pacemaker activities of ICCs in the murine small intestine are mainly due to periodic activations of nonselective cation channels (NSCCs) [32,33] or $\mathrm{Cl}^{-}$channels [34-36]. Kim et al. [24] suggested transient receptor potential melastatin (TRPM) 7 is required for ICC pacemaker activity in the murine small intestine, and that a $\mathrm{Ca}^{2+}$-activated $\mathrm{Cl}^{-}$channel (CaCC) is involved in the slow waves generated by ICCs; this $\mathrm{Cl}^{-}$channel was later identified as transmembrane protein 16A (Tmem16A; anoctamin1 (ANO1)) [35]. The role played by ANO1 in ICC pacemaker activity was identified in ANO1 knockout mice [37], and several other authors have since shown that ANO1 participates in pacemaker activity [38, 39]. Kim et al. $[24,40]$ showed that TRPM7 mRNA and TRPM7 currents are expressed in cultured ICCs, and Shahi et al. $[40,41]$ showed that ANO1 mRNA and ANO1 currents are also expressed in cultured ICCs. Accordingly, it has been proposed that TRPM7 and ANO1 be considered potential targets for the pharmacological treatment of GI motility disorders.

Quercetin plays a vital role in the GI system [42-46], but relatively little is known about its effects on the pacemaker activities of ICCs in the GI tract or on GI motility-related ion channel activities. In the present study, we investigated the inhibitory effects of quercetin on the pacemaker potentials of cultured ICCs, and characterized quercetin-mediated signaling pathways. In addition, we investigated the inhibitory effects of quercetin on GI motor functions by measuring the intestinal transit rates (ITR) of Evans blue in normal mice. 


\section{Cellular Physiology Cell Physiol Biochem 2015;35:2422-2436

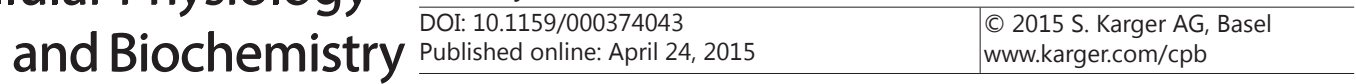 \\ Gim et al.: Effects of Quercetin on ICCS}

\section{Materials and Methods}

Preparation of cells and cell cultures

Animal care and experiments were conducted in accordance with the guidelines issued by the ethics committee of Pusan National University (Republic of Korea). Balb/c mice were used throughout the study. Small intestines (from $1 \mathrm{~cm}$ below the pyloric ring to the cecum) were removed and opened along the mesenteric border. Luminal contents were removed using Krebs-Ringer bicarbonate solution, and the tissues obtained were pinned to the base of Sylgard dishes. Mucosae were removed by sharp dissection and small tissue strips of intestine muscle (consisting of circular and longitudinal muscles) were equilibrated for 30 min in $\mathrm{Ca}^{2+}$-free Hank's solution (containing (in mM); $\mathrm{KCl} 5.36, \mathrm{NaCl} 125, \mathrm{NaOH} \mathrm{0.34,} \mathrm{Na}_{2} \mathrm{HCO}_{3} 0.44$, glucose 10, sucrose 2.9 and HEPES 11; pH 7.4). Cells were then dispersed in an enzyme solution containing collagenase (Worthington Biochemical, Lakewood, NJ, USA; $1.3 \mathrm{mg} \mathrm{ml}^{-1}$ ), bovine serum albumin (BSA, Sigma-Aldrich, St Louis, MO; $2 \mathrm{mg} \mathrm{ml}^{-1}$ ), trypsin inhibitor (Sigma-Aldrich; $2 \mathrm{mg} \mathrm{ml}^{-1}$ ), and ATP (0.27 mg $\left.\mathrm{ml}^{-1}\right)$, and plated onto sterile glass coverslips coated with murine collagen $\left(2.5 \mu \mathrm{g} \mathrm{ml}^{-1}\right.$; Falcon/BD, Franklin Lakes, NJ, USA) in $35 \mathrm{~mm}$ culture dishes. Cells were then cultured at $37^{\circ} \mathrm{C}$ in a $95 \% \mathrm{O}_{2}-5 \% \mathrm{CO}_{2}$ incubator in smooth muscle growth medium (SMGM; Clonetics, San Diego, CA, USA) supplemented with 2\% antibiotics/ antimycotics (Gibco, Grand Island, NY, USA) and murine stem cell factor (SCF; $5 \mathrm{ng} \mathrm{ml}^{-1}$; Sigma-Aldrich). All experiments on ICC clusters were performed after culture for $12 \mathrm{hrs}$. ICCs were identified immunologically using an anti-c-kit antibody (phycoerythrin (PE)-conjugated rat anti-mouse c-kit monoclonal antibody; eBioscience, San Diego, CA) at a dilution of 1:50 for $20 \mathrm{~min}$ (Fig. 1). ICCs were morphologically distinct from other cell types in the culture and thus it was possible to identify the cells by phase contrast microscopy once they had been verified with anti c-kit antibody.

\section{Patch-clamp experiments}

The physiological salt solution used to bathe cultured ICC clusters ( $\mathrm{Na}^{+}$-Tyrode) contained (in $\mathrm{mM}$ ): $\mathrm{KCl} 5, \mathrm{NaCl} 135, \mathrm{CaCl}_{2} 2$, glucose 10, $\mathrm{MgCl}_{2}$ 1.2, and HEPES 10 (adjusted to $\mathrm{pH} 7.4$ with $\mathrm{NaOH}$ ). The pipette solution used to examine pacemaker activity contained (in mM): $\mathrm{KCl} 140, \mathrm{MgCl}_{2} 5, \mathrm{~K}_{2} \mathrm{ATP} 2.7$, NaGTP 0.1, creatine phosphate disodium 2.5, HEPES 5, and EGTA 0.1 (adjusted to pH 7.2 with KOH). Patch-clamp techniques were conducted in whole-cell configuration to record membrane currents (voltage clamp mode) and potentials (current clamp mode) from cultured ICCs using Axopatch I-D and Axopatch 200B amplifiers (Axon Instruments, Foster, CA). Command pulses were applied using an IBM-compatible personal computer and pClamp software (version 6.1 and version 10.0; Axon Instruments). Data were filtered at $5 \mathrm{kHz}$ and displayed on an oscilloscope, a computer monitor, and/or a pen recorder (Gould 2200; Gould, Valley View, OH, USA). Results were analyzed using pClamp and Origin software (version 6.0, Microcal, USA). All experiments were performed at $30-33^{\circ} \mathrm{C}$.

$\mathrm{Ca}^{2+}$ activated $\mathrm{Cl}$ channel expression in human embryonic kidney (HEK)-293T cells

A mammalian expressible plasmid for mouse AN01/TMEM16A (pEGFP-N1-mAN01, ac isoform) was generously provided by Dr. Min Goo Lee (Yonsei University, Korea). Plasmids were transiently transfected into human embryonic kidney (HEK) 293T cells using Lipofectamine Plus Reagent (Life Technologies, USA), according to the manufacturer's instructions. Briefly, HEK293T cells were cultured in DMEM supplemented

Fig. 1. Cultured ICCs from murine small intestine. Tunica muscularis of small bowel was digested with collagenase, and dispersed cells were cultured for 12 hours. This confocal microscope image shows Kit immunopositive ICCs in culture. Scale bar: $10 \mu \mathrm{m}$.

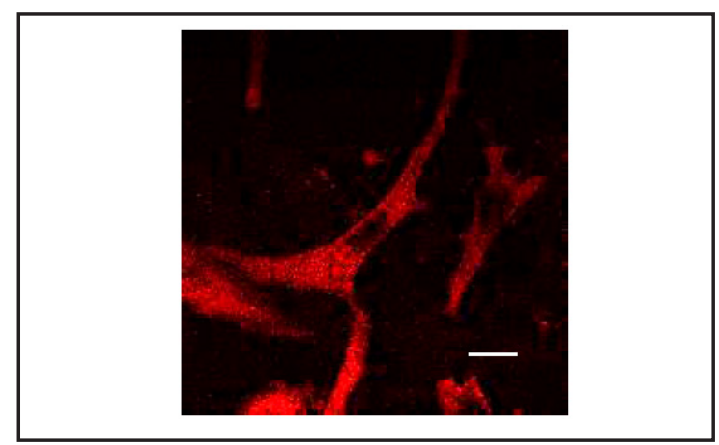




\section{Cellular Physiology Cell Physiol Biochem 2015;35:2422-2436 \begin{tabular}{ll|l} 
and 10.1159/000374043 & $\begin{array}{l}\text { O 2015 S. Karger AG, Basel } \\
\text { www.karger.com/cpb }\end{array}$ \\
\hline
\end{tabular} \\ Gim et al.: Effects of Quercetin on ICCs}

with $10 \%$ fetal bovine serum and $0.5 \%$ penicillin-streptomycin at $37^{\circ} \mathrm{C}$ in a $90 \% \mathrm{O}_{2}-10 \% \mathrm{CO}_{2}$ incubator. One day before transfection, cells were transferred on glass coverslips. For electrophysiological experiments, HEK293T cells were transfected with $0.9 \mu \mathrm{g}$ of mANO1 plasmid and $0.1 \mu \mathrm{g}$ of a plasmid expressing green fluorescent protein (pEGFP-N1). Cells transfected with $1 \mu \mathrm{g}$ of pEGFP-N1 were used as negative controls. HEK-293T cells were routinely studied at $21-25^{\circ} \mathrm{C}, 24 \mathrm{~h}$ after transfection. The bath solution contained 146 $\mathrm{mM} \mathrm{HCl}, 10 \mathrm{mM}$ HEPES, $10 \mathrm{mM}$ glucose, $1 \mathrm{mM} \mathrm{MgCl}{ }_{2}, 1 \mathrm{mM} \mathrm{CaCl}_{2}$, and $150 \mathrm{mM} \mathrm{N}$-methyl-D-glucamine (NMDG), adjusted to $\mathrm{pH}$ 7.4. The pipette solution contained $150 \mathrm{mM}$ NMDG-Cl, $1 \mathrm{mM} \mathrm{MgCl}{ }_{2}, 3 \mathrm{mM}$ MgATP, 10 mM EGTA, $5 \mathrm{mM} \mathrm{CaCl}_{2}$ and $5 \mathrm{mM}$ HEPES at pH 7.2 (titrated with NMDG). The free calcium concentration was fixed at $200 \mathrm{nM}$ using WEBMAX-C software (C. Patton, Stanford University, www.stanford. edu/ cpatton/ maxc.html).

TRPM7 Expression in HEK-293T cells

HEK-293T cells transfected with the Flag-murine LTRPC7 /pCDNA4-TO construct were grown on glass coverslips in Dulbecco's modified Eagle medium supplemented with $10 \%$ fetal bovine serum, blasticidin ( 5 $\mu \mathrm{g} / \mathrm{ml}$ ), and zeocin $(0.4 \mathrm{mg} / \mathrm{ml}$ ). TRPM7 (LTRPC7) expression was induced by adding $1 \mu \mathrm{g} / \mathrm{ml}$ tetracycline to culture medium. Whole-cell patch-clamp experiments were performed at $21-25^{\circ} \mathrm{C} 24 \mathrm{~h}$ after induction using cells grown on glass coverslips. The internal pipette solution for whole cell current recordings contained (in mM) 145 Cs-methanesulfonate, $8 \mathrm{NaCl}, 10 \mathrm{Cs}$-2-bis(2-aminophenoxy)-ethane- $\mathrm{N}, \mathrm{N}, \mathrm{N}^{\prime}, \mathrm{N}^{\prime}$-tetraacetic acid, and 10 HEPES-CsOH adjusted to $\mathrm{pH} 7.2$ with $\mathrm{CsOH}$. The standard extracellular Tyrode's solution contained (in $\mathrm{mM}$ ) $145 \mathrm{NaCl}, 2.8 \mathrm{KCl}, 2 \mathrm{CaCl} 2,1.2 \mathrm{MgCl} 2,10 \mathrm{HEPES}$, and 10 glucose, adjusted to $\mathrm{pH} 7.4$ with $\mathrm{NaOH}$. All experiments were performed at $21-25^{\circ} \mathrm{C}$.

cAMP and cGMP assay

ICCs were preincubated with $100 \mu \mathrm{M}$ IBMX for $30 \mathrm{~min}$ at $37^{\circ} \mathrm{C}$ to inhibit cAMP and cGMP degradation and then incubated with quercetin $(200 \mu \mathrm{M})$ for $10 \mathrm{~min}$. Cells were then homogenized in buffer containing 4 mM EDTA to prevent the degradations of enzymatic cAMP or cGMP and homogenates were then heated for $5 \mathrm{~min}$ in a boiling water bath to coagulate protein. After centrifugation at 3,000 rpm for $5 \mathrm{~min}$, supernatants were transferred to new tubes and stored at $4^{\circ} \mathrm{C}$. Samples were assayed for cAMP or cGMP using cAMP or cGMP ELISA kits (Enzo Life Science, Farmingdale, NY, USA).

\section{Measurement of Evans blue ITRs}

The effects of quercetin on intestinal motility were assessed by measuring the intestinal transit rates (ITRs) of Evans blue solution (5 \%, w/v, in DW). Briefly, $30 \mathrm{~min}$ after the intragastric (i.g.) administration of quercetin to normal mice, $0.1 \mathrm{ml}$ of Evans blue solution was administered i.g. through an orogastric tube. Animals were sacrificed $30 \mathrm{~min}$ after this administration, and intestinal transit was determined by measuring the distance that the Evans blue had migrated in intestines from the pylorus. ITR (\%) were calculated by expressing the distance traveled by the dye as a percentage of the total length of small intestine (from the pylorus to the ileal end). To minimize possible inter-day variations, all measurements were performed on same days.

Drugs

Quercetin was purchased from Alexis Biochemicals (Vinci Biochem, Florence, Italy) and naloxone from TOCRIS (USA). All other drugs were obtained from Sigma. Stock solutions were prepared and stored, according to the manufacturer's instructions. Chemicals were dissolved in $\mathrm{Na}^{+}$-Tyrode solution to their final concentrations immediately before use.

\section{Statistical analysis}

Results are expressed as means \pm SEMs. Statistical analysis was performed using the student's $t$ test or by analysis of variance (ANOVA) followed by Tukey's multiple comparison test, as appropriate. The analysis was performed using GraphPad Prism version 6, and $p$ values of $<0.05$ were considered statistically significant. The $n$ values reported in the text refer to the number of cells used in patch-clamp experiments. 
A)
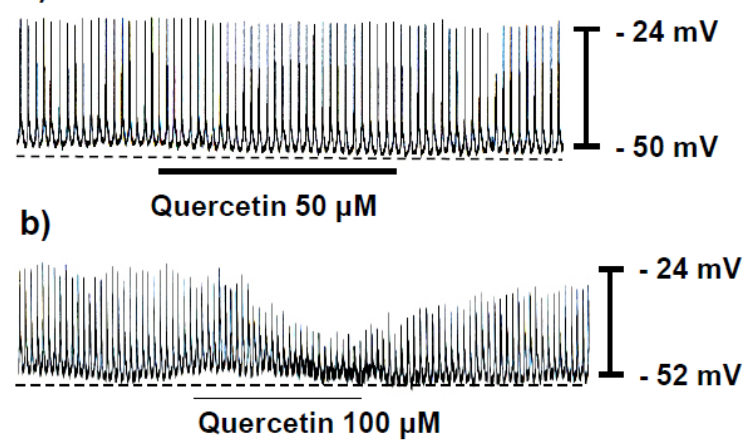

c)

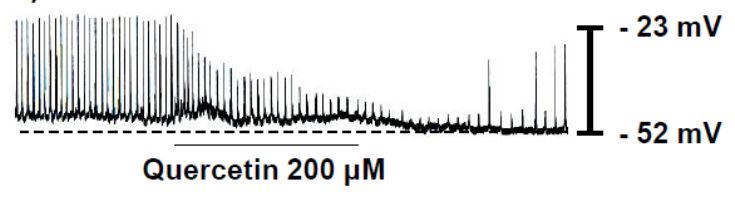

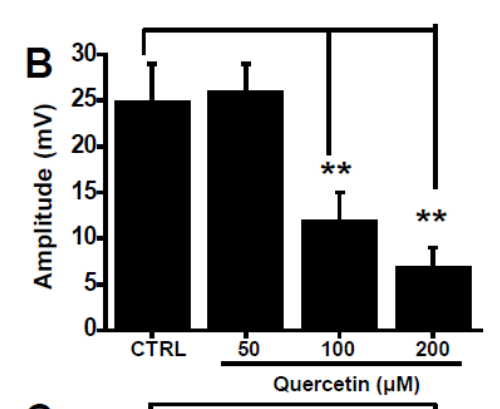
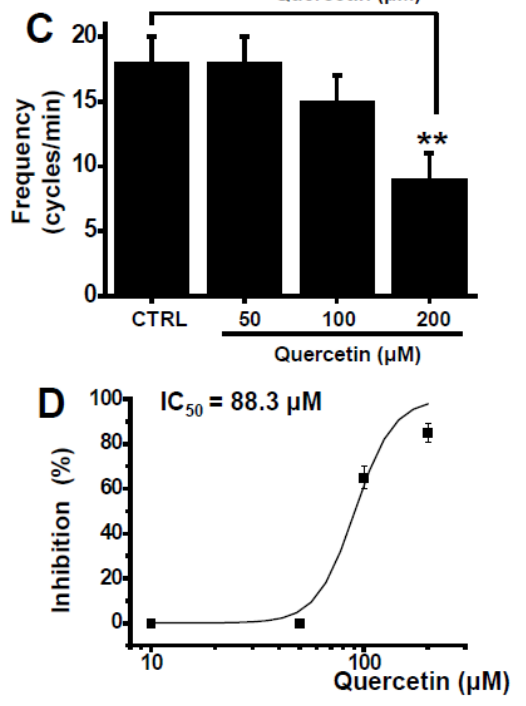

Fig. 2. Effects of quercetin on the pacemaker activity of cultured ICC clusters. (A) Pacemaker activities of ICCs exposed to quercetin (50-200 $\mu \mathrm{M})$ in current-clamp mode ( $\mathrm{I}=0)$. Quercetin decreased pacemaker amplitude and frequency in a concentration-dependent manner. Responses to quercetin are summarized in (B and C). (D) Concentration-dependent inhibition of ICC pacemaker activity by quercetin. The estimated median inhibitory concentration value for quercetin was $88.3 \mu \mathrm{M}$. Bars represent means \pm SEs. CTRL: Control. ${ }^{* *} P<0.01$.

\section{Results}

Inhibitory effects of quercetin on the pacemaker activities of cultured ICCs

Cultured ICC clusters had a mean resting membrane potential of $-51 \pm 5 \mathrm{mV}$ and produced electrical pacemaker activity at a frequency of $17 \pm 2$ cycles per minute and an amplitude of $25 \pm 4 \mathrm{mV}(\mathrm{n}=40)$ at $30^{\circ} \mathrm{C}$ in current clamp mode. Quercetin at concentrations from 100 to $200 \mu \mathrm{M}$ decreased pacemaker amplitude and frequency in a concentrationdependent manner with an $\mathrm{IC}_{50}$ of $\sim 88.3 \mu \mathrm{M}$ (Fig. 2).

\section{Effects of potassium channel blockers on pacemaker activity inhibition by quercetin}

To investigate which potassium channels mediate quercetin-induced pacemaker activity, we used various potassium channel blocker types. The treatment of ICCs with tetraethylammonium chloride (TEA) $\left(10 \mathrm{mM}\right.$; a Ca ${ }^{2+}$-activated $\mathrm{K}^{+}$channel blocker) or $\mathrm{BaCl}_{2}$ ( $50 \mu \mathrm{M}$; an inward rectifying $\mathrm{K}^{+}$channel blocker) had no effect on pacemaker activities, and in the presence of TEA or $\mathrm{BaCl}_{2}$, quercetin still inhibited pacemaker activities ( $\mathrm{n}=5$; Fig. 3Aa, $3 \mathrm{Ab}$ and $3 \mathrm{~B})$. In addition, treatments with glibenclamide $\left(10 \mu \mathrm{M}\right.$; an ATP-sensitive $\mathrm{K}^{+}$channel blocker), 4-aminopyridine ( $5 \mathrm{mM}$; a transient voltage-dependent $\mathrm{K}^{+}$channel blocker), or apamin $\left(1 \mu \mathrm{M}\right.$; a $\mathrm{Ca}^{2+}$-activated $\mathrm{K}^{+}$channel blocker) had no effect on pacemaker activity, 


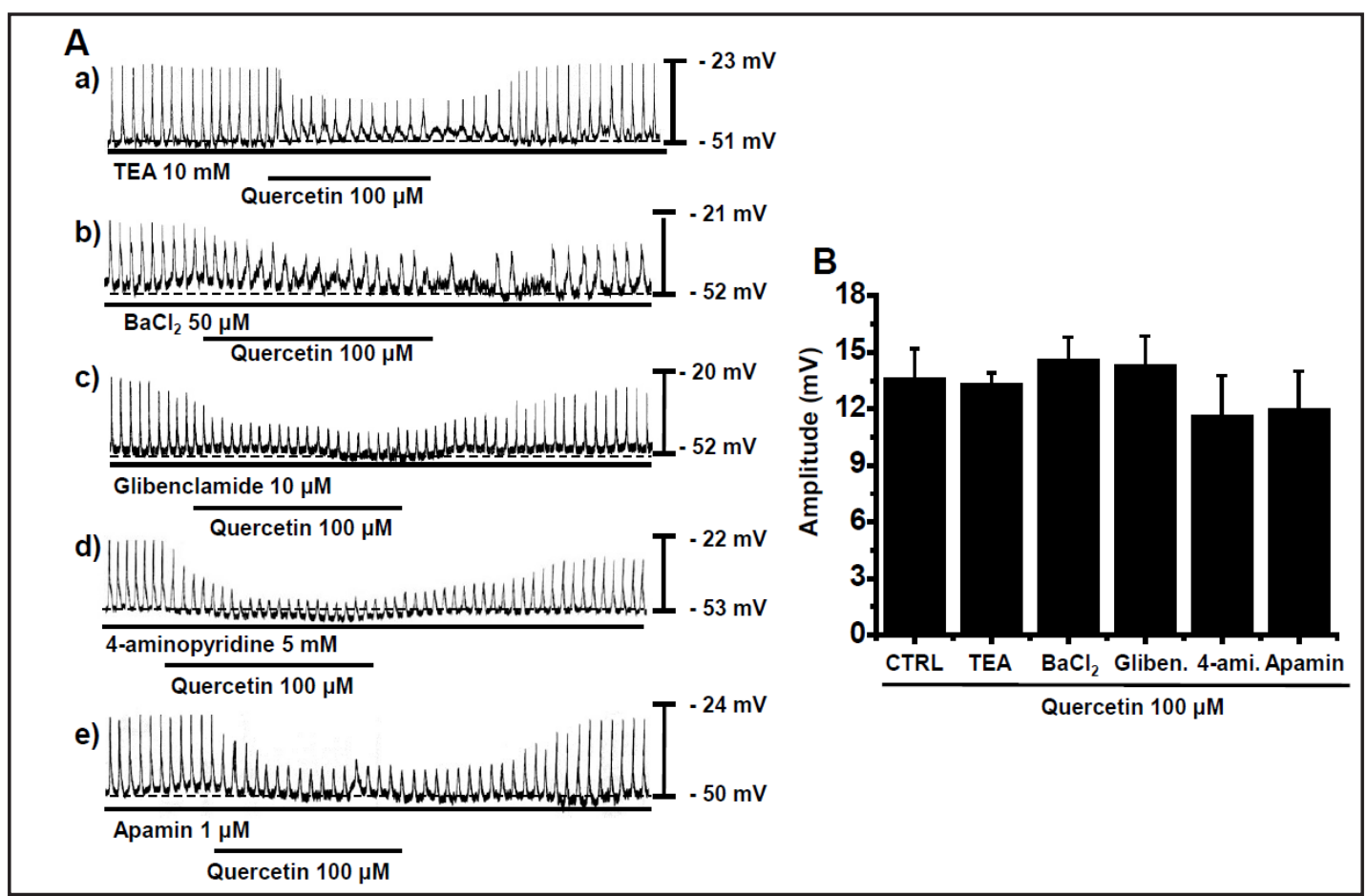

Fig. 3. Effects of TEA, $\mathrm{BaCl}_{2}$, glibenclamide, 4-aminopyridine, and apamin on pacemaker activity inhibition by quercetin in cultured ICC clusters. Pretreatment with (Aa) TEA (10 mM), (Ab) $\mathrm{BaCl}_{2}(50 \mu \mathrm{M})$, (Ac) glibenclamide $(10 \mu \mathrm{M}),(\mathrm{Ad})$ 4-aminopyridine $(5 \mathrm{mM})$, or $(\mathrm{Ae})$ apamin $(1 \mu \mathrm{M})$ did not affect the inhibitory effects of quercetin. Responses to quercetin in the presence of potassium channel blockers are summarized in (B). TEA: tetraethylammonium chloride.

Fig. 4. Effects of naloxone, a pan opioid receptor antagonist, on pacemaker activity inhibition by quercetin in cultured ICC clusters. (A) Effects of naloxone (a pan opioid receptor antagonist) on pacemaker activity inhibition by quercetin. Naloxone blocked the inhibitory effects of quercetin. (B) Responses to quercetin in the presence of naloxone are summarized. Bars represent means \pm SEs. CTRL: Control. ${ }^{* *} P<0.01$.

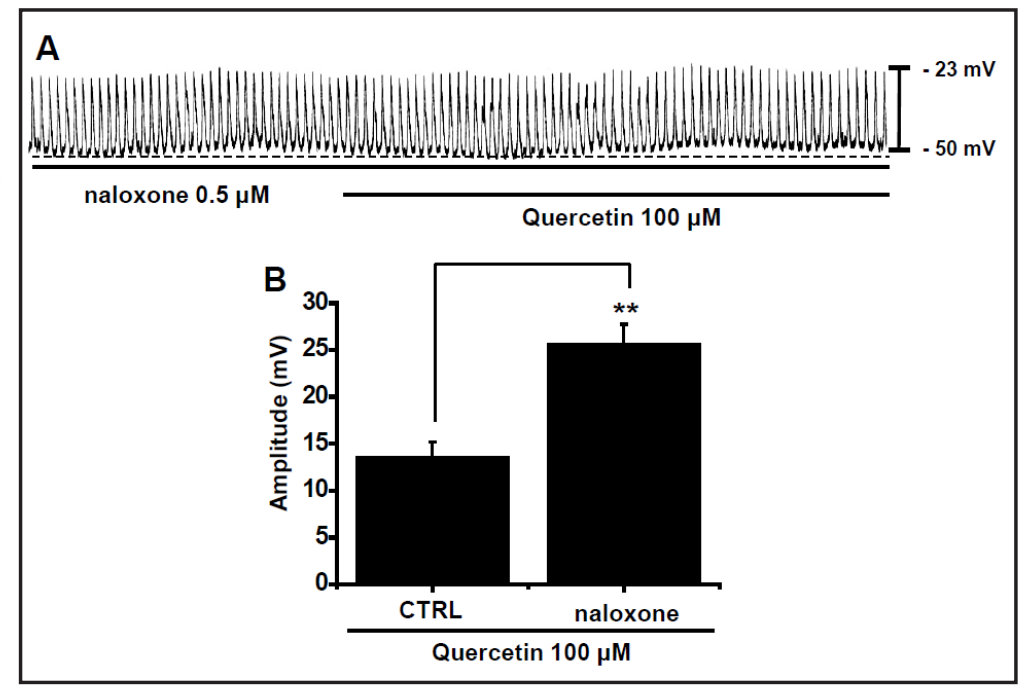

and quercetin still inhibited pacemaker activities when co-treated with glibenclamide, 4-aminopyridine, or apamin ( $n=5$; Fig. 3Ac, 3Ad, 3Ae and 3B).

Effects of opioid receptors on pacemaker activity inhibition by quercetin

Opioid receptor antagonists, such as, naloxone, are used to treat bowel diseases [47], and numerous studies have described the pharmacological effects of naloxone on GI motility in vitro in guinea pigs, rodents, and humans [48-52]. Therefore, we investigated the relationship between quercetin and opioid receptors by examining the effect of naloxone (a 
Fig. 5. Effects of GDP $\beta$ S in the pipette on pacemaker activity inhibition by quercetin in cultured ICC clusters. (A) Pacemaker activities of ICCs exposed to quercetin in the presence of GDP $\beta$ S (1 $\mathrm{mM}$ ) in the pipette solution. Under these conditions, quercetin had no effect on pacemaker activity. (B) Responses to quercetin in the presence of GDP $\beta S$ in the pipette are summarized. Bars represent means \pm SEs. CTRL: Control. $* * P<0.01$.

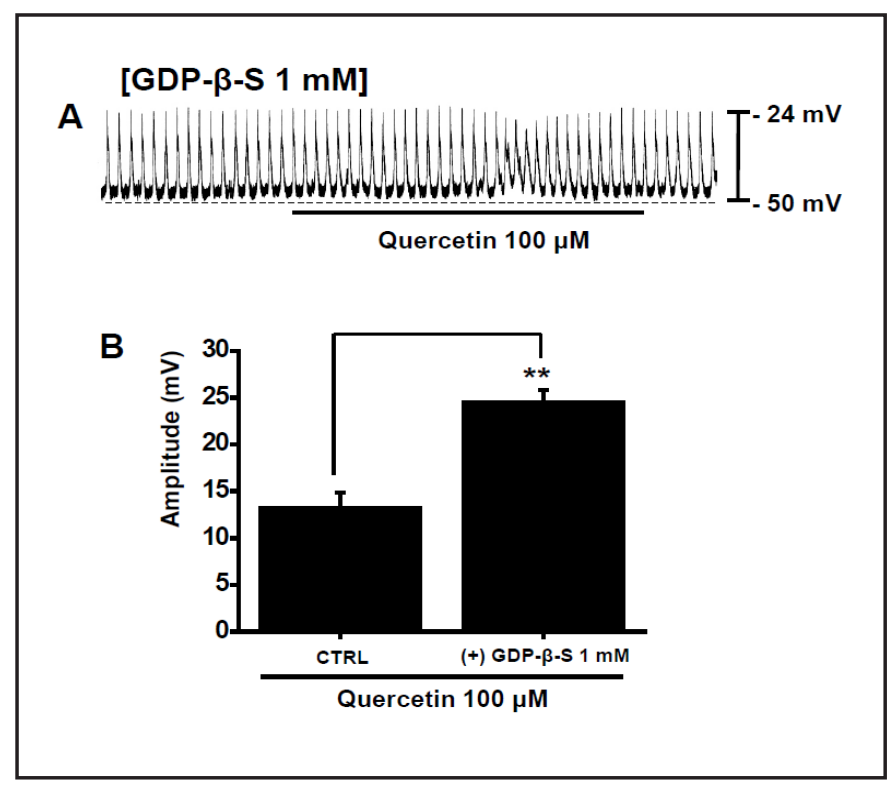

pan-opioid receptor antagonist) on pacemaker activity inhibition by quercetin. In the absence of naloxone, quercetin decreased the pacemaker activity amplitude and frequency (Fig. 2), but naloxone prevented pacemaker activity inhibition by quercetin (Fig. 4A) (pacemaker activity amplitude was $24 \pm 4 \mathrm{mV}$ in the presence of naloxone (Fig. 4B)).

Involvement of $G$ proteins in pacemaker activity inhibition by quercetin

To investigate the signaling mechanisms involved and the roles played by G proteins during pacemaker activity inhibition by quercetin, we applied GDP $\beta S$ ( $1 \mathrm{mM}$; a nonhydrolysable guanosine $5^{\prime}$-diphosphate analogue that permanently inactivates GTP binding proteins $[53,54])$ to the patch pipette solution, and this resulted in the prevention of pacemaker activity inhibition by quercetin $(n=5$; Fig. 5A). Mean depolarizations were 24.6 $\pm 1.2 \mathrm{mV}$ and in the presence and absence of GDP $\beta$ S (Fig. 5B).

Involvement of guanylate cyclase, protein kinase $G$ and nitric oxide in pacemaker activity inhibition by quercetin

To investigate whether pacemaker activity inhibition by quercetin is mediated by a cyclic nucleotide-dependent pathways, we used SQ-22536, an inhibitor of adenylate cyclase, and $1 \mathrm{H}-[1,2,4]$ oxadiazolo [4, 3-a]quinoxalin-1-one (ODQ), an inhibitor of guanylate cyclase. Preincubation of ICCs with SQ-22536 $(100 \mu \mathrm{M})$ for $10 \mathrm{~min}$ had no effect on pacemaker activity, and in the presence of SQ-22536, quercetin $(100 \mu \mathrm{M})$ still inhibited pacemaker activity $(\mathrm{n}=6$; Fig. 6Aa and 6B). However, ODQ $(100 \mu \mathrm{M})$ blocked pacemaker activity inhibition by quercetin $(n=6$; Fig. $6 \mathrm{Ac}$ and $6 \mathrm{~B})$. Also, to see whether the pacemaker activity inhibition by quercetin was mediated by cAMP-dependent protein kinase A (PKA) or cGMPdependent protein kinase G (PKG), we examined the effects of myristoylated PKA inhibitor (an inhibitor of PKA) and RP-8-CPT-cGMPS (an inhibitor of PKG). Preincubation of ICCs with myristoylated PKA inhibitor $(1 \mu \mathrm{M})$ had no effect on pacemaker activities, and in the presence of myristoylated PKA inhibitor, quercetin inhibited pacemaker activities $(n=5$; Fig. 6Ab and 6B). However, in the presence of RP-8-CPT-cGMPS $(10 \mu \mathrm{M})$, quercetin failed to inhibit pacemaker activities $(\mathrm{n}=5$; Fig. 6Ad and 6B). Nitric oxide (NO) activates soluble guanylyl cyclase, which results in the formation of cGMP and in the activation of PKG [55]. To investigate whether pacemaker activity inhibition by quercetin is mediated by NO, we added L-NAME (100 $\mu \mathrm{M}$; a non-selective NO synthases (NOS)) inhibitor, and found that it blocked pacemaker activity inhibition by quercetin $(n=5$; Fig. 6Ae and $6 \mathrm{~B})$. In addition, 
A

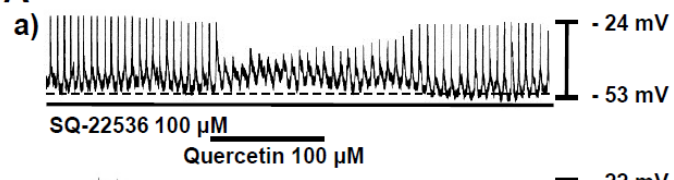

b)

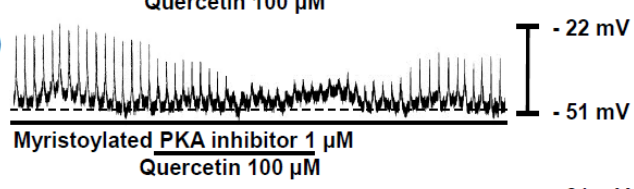

c)

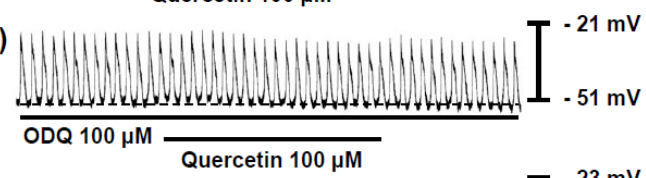

d)

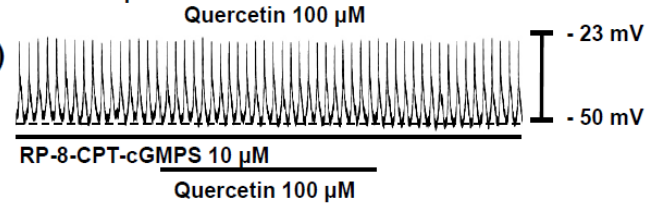

e)
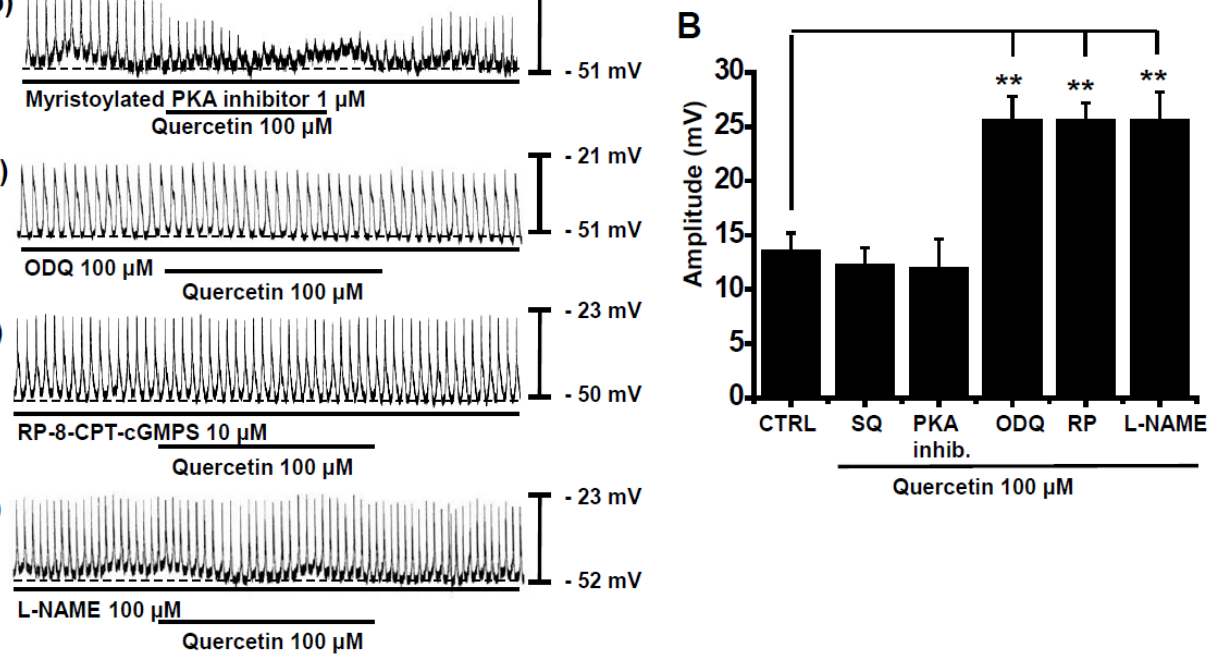

Fig. 6. Effects of SQ-22536 (an inhibitor of adenylate cyclase), ODQ (an inhibitor of guanylate cyclase), myristoylated PKA inhibitor, RP-8-CPT-cGMPS (an inhibitor of PKG) and L-NAME (a non-selective NO synthases (NOS) inhibitor) on pacemaker activity inhibition by quercetin in cultured ICC clusters. (Aa) Pacemaker activities of ICCs exposed to quercetin in the presence of SQ-22536 (100 $\mu \mathrm{M})$. SQ-22536 had no effects on the inhibitory effects of quercetin on pacemaker activity. (Ab) Treatment with myristoylated PKA inhibitor (1 $\mu \mathrm{M})$ had no effect on pacemaker activity inhibition by quercetin and under these conditions, this inhibition was not suppressed by a myristoylated PKA inhibitor. Pacemaker activities of ICCs exposed to quercetin in the presence of (Ac) ODQ $(100 \mu \mathrm{M})$, (Ad) RP-8-CPT-cGMPS $(10 \mu \mathrm{M})$, or (Ae) L-NAME $(100 \mu \mathrm{M})$. ODQ, RP-8CPT-cGMPS, or L-NAME blocked pacemaker activity inhibition by quercetin. (B) Responses to quercetin in the presence of SQ-22536, ODQ myristoylated PKA inhibitor, RP-8-CPT-cGMPS, and L-NAME are summarized. Bars represent means \pm SEs. CTRL: Control. ${ }^{* *} P<0.01$.
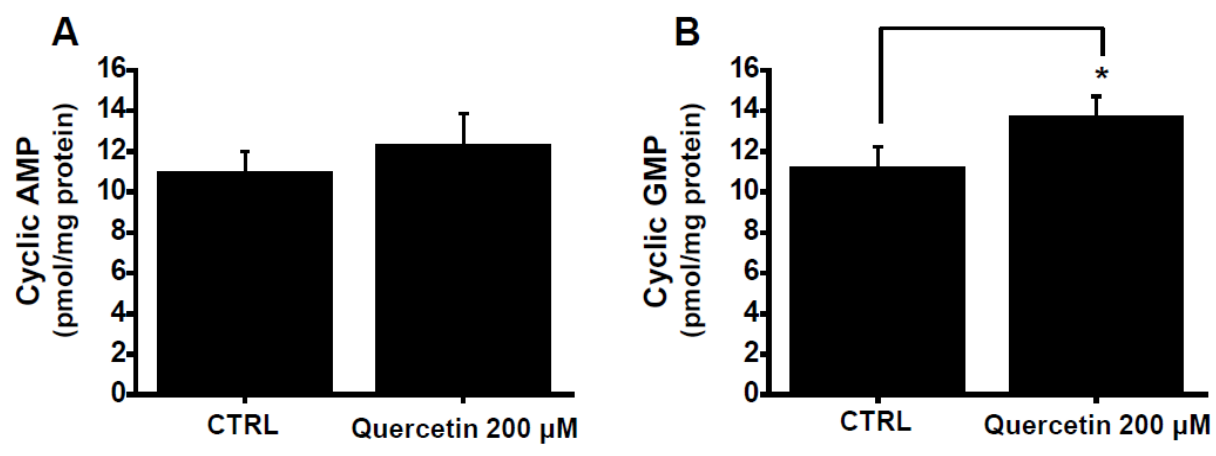

Fig. 7. Effects of cAMP and cGMP production on pacemaker activity inhibition by quercetin in cultured ICC clusters. (A) Preincubation of ICC with quercetin $(200 \mu \mathrm{M})$ did not significantly stimulate cAMP production. (B) However, preincubation of ICC plus quercetin $(200 \mu \mathrm{M})$ significantly stimulated cGMP production. Bars represent means \pm SEs. CTRL: Control. ${ }^{*} P<0.05$.

to determine whether changes in cAMP and cGMP contents are involved in the inhibitory effect of quercetin on ICCs, intracellular cAMP and cGMP contents were measured under basal and quercetin-stimulated conditions. Quercetin did not stimulate cAMP production 


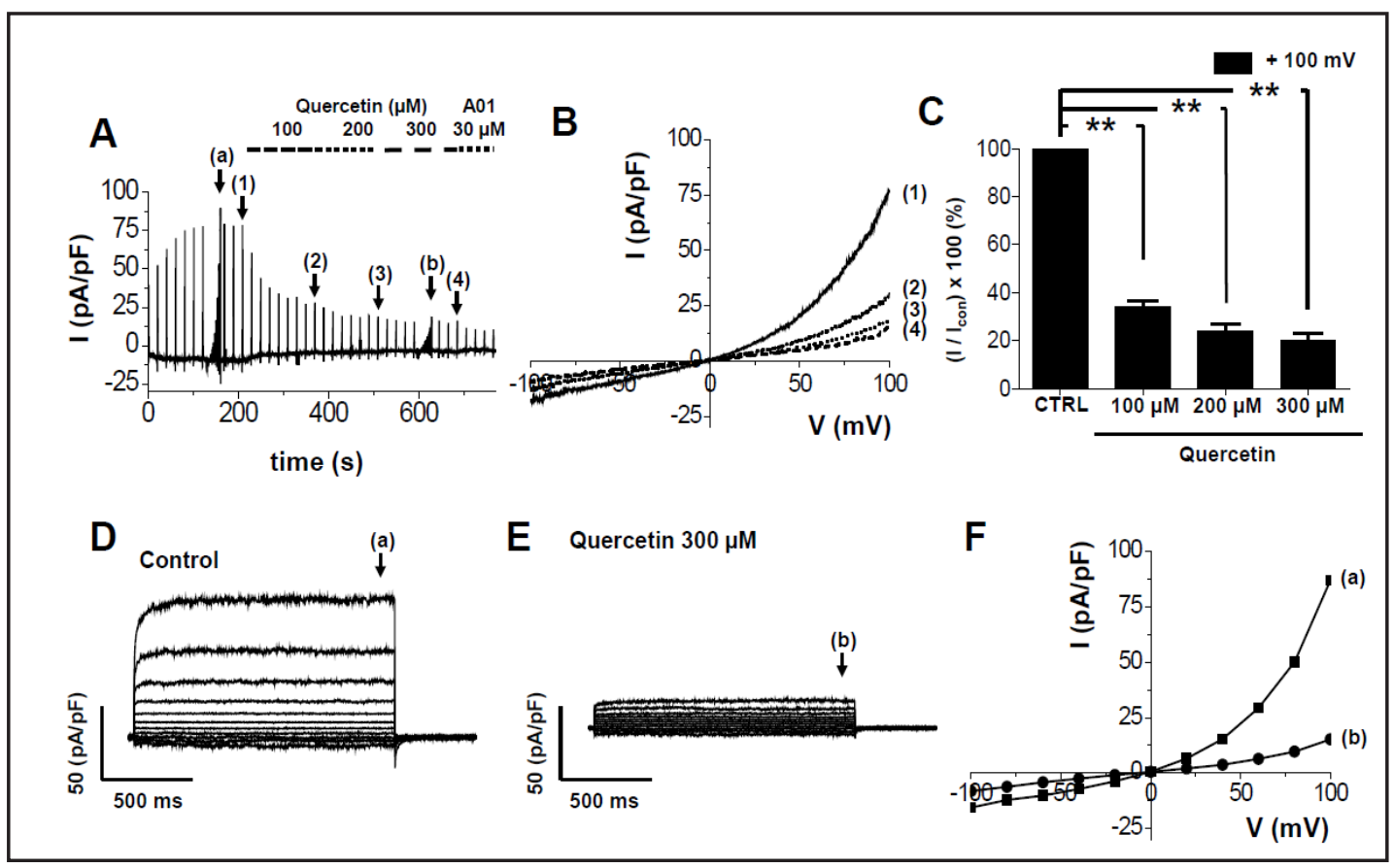

Fig. 8. Effect of quercetin on $\mathrm{I}_{\mathrm{ANO} 1}$ currents in ANO1 overexpressing HEK 293 cells and on the current-voltage (I-V) relationship using the whole cell patch-clamp technique. (A) Representative trace of ${ }_{\text {ANO1 }}$ inhibition by quercetin. After confirming $\mathrm{I}_{\mathrm{ANO} 1}$ activation, quercetin was applied at 100, 200, or $300 \mu \mathrm{M}$ to hANO1-overexpressing HEK293T cells. (B) Representative I-V relationship curve at peak $\mathrm{I}_{\mathrm{ANO1}}$ current (1), and after treatment with 100 (2), 200 (3), or 300 (4) $\mu \mathrm{M}$ of quercetin. (C) Summary of the inhibition rates of $\mathrm{I}_{\mathrm{ANO1}}$ at +100 $\mathrm{mV} .{ }^{*} P<0.01 \mathrm{vs}$. the CTRL (control). (D) Representative raw current traces obtained from step-pulses at point (a) in Fig. 7A, which is the steady-state peak current of $\mathrm{I}_{\text {ANO1 }}$. Voltage steps (1500 ms) were used from a holding potential of $-60 \mathrm{mV}$ to voltages between $-100 \mathrm{and}+100 \mathrm{mV}$ in $20 \mathrm{mV}$ increments, followed by a step to $-60 \mathrm{mV}$. (E) Representative raw current traces obtained from step pulses at point (b) in Fig. 7A, which is the $\mathrm{I}_{\mathrm{ANO} 1}$ steady-state current obtained in the presence of $300 \mu \mathrm{M}$ quercetin. The same step pulse protocol is shown in Fig. 7D. (F) Steady-state current-voltage relationships for the control and treatment with 300 $\mu \mathrm{M}$ quercetin. I-V relationships were constructed from currents recorded at the points shown in Fig. 7D (a) and Fig. 7E (b).

(Fig. 7A; control: $11.1 \pm 1.2$ vs. quercetin: $12.3 \pm 1.4 \mathrm{pmol} / \mathrm{mg}-1$ protein), but stimulated cGMP production (Fig. 7B; control: $11.3 \pm 1.1$ vs. quercetin: $13.8 \pm 1.3 \mathrm{pmol} / \mathrm{mg}-1$ protein).

Involvements of ANO1 and TRPM7 channels during pacemaker activity inhibition by quercetin

It has been reported ANO1 and TRPM7 are involved in slow wave generation and that they are required for ICC pacemaker activity in the murine small intestine [24, 35]. Furthermore, TRPM7 and ANO1 mRNA have been reported in ICCs and TRPM7 and ANO1 currents have been described [24, 35, 40,41]. Thus, we examined the effects of quercetin on the expressions of ANO1 and TRPM7 channels in HEK 293 cells, which overexpress both channels. To investigate whether ANO1 channels are involved in the pacemaker activity of ICCs, we performed whole-cell patch clamp recordings on hANO1-transfected HEK293T cells using a $200 \mathrm{nM}$ free $\mathrm{Ca}^{2+}$ pipette solution to activate ANO1 currents $\left(\mathrm{I}_{\mathrm{ANO1}}\right)$. Fig. 8A shows representative $\mathrm{I}_{\mathrm{ANO} 1}$ recordings and its inhibition by different concentrations of quercetin. After membrane break-in, an outward rectifying $\mathrm{Cl}^{-}$current was immediately activated by diffusion of the pipette solution. After confirming a steady-state current level, we applied depolarizing step pulses from $-100 \mathrm{mV}$ to $+100 \mathrm{mV}$ (Fig. 8A (a)). Using step depolarization, delayed activation of outward currents and a deactivation tail current were observed, which 


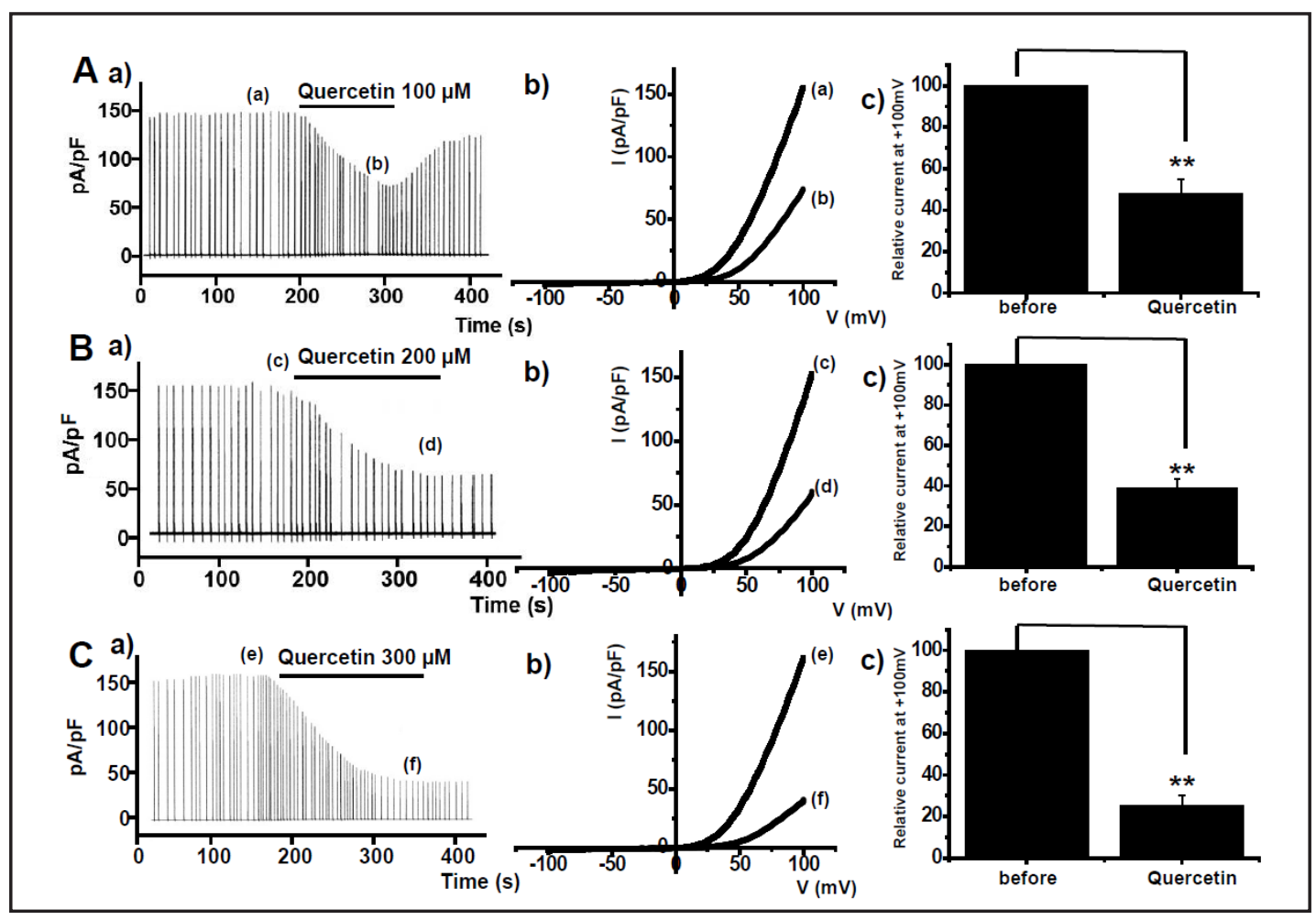

Fig. 9. Effects of quercetin on TRPM7 currents in TRPM7 overexpressing HEK 293 cells and current-voltage (I-V) relationship obtained using the whole cell patch-clamp technique. (Aa, Ba and Ca) Quercetin inhibited TRPM7 currents in TRPM7 overexpressing HEK 293 cells. Slow ramp depolarizations from +100 to -100 mV were applied from a holding potential of $-60 \mathrm{mV}$ before (a) and during (b) treatment with quercetin. (Ab, $\mathrm{Bb}$ and $\mathrm{Cb}$ ) I-V relationships were determined before and during treatment. (Ac, Bc and $\mathrm{Cc}$ ) Responses to quercetin during TRPM7 currents are summarized. Bars represent means \pm SEs. ${ }^{* *} P<0.01$.

are typical characteristics of $\mathrm{I}_{\mathrm{ANO} 0}$ (Fig. 8D) Fig. 8F (a) shows the steady-state I-V relationship from step depolarization of the untreated control (black arrow). Next, we serially perfused cells with quercetin-containing bath solution $(100,200$, or $300 \mu \mathrm{M})$. Quercetin significantly inhibited $\mathrm{I}_{\mathrm{AN} 01}$ currents. The associated I-V relationship curves at peak $\mathrm{I}_{\mathrm{ANO} 1}(1)$ and at quercetin concentrations of 100 (2), 200 (3), or $300 \mu \mathrm{M}$ (4) were obtained using a ramp-like pulse protocol from $-100 \mathrm{mV}$ to $+100 \mathrm{mV}$ (Fig. 8B). After treatment with $300 \mu \mathrm{M}$ quercetin, we again applied the step-pulse, and found that $300 \mu \mathrm{M}$ quercetin almost completely inhibited $\mathrm{I}_{\mathrm{ANO1}}$ current (Fig. 8E). Relative steady-state I-V relationships are presented in Fig. 8F (b). To compare inhibitory effects on ANO1, we treated cells with $30 \mu \mathrm{M}$ T16Ainh-A01 (a selective ANO1 inhibitor) at the end of the experiment as a positive control. To determine inhibitory percentages at each concentration, the normalized amplitudes of the currents $\left(\mathrm{I}_{\text {ext }} / \mathrm{I}_{\text {con }} \times 100 \%\right)$ of quercetin-treated cells were measured at $+100 \mathrm{mV}$. As shown in Fig. 8C, quercetin significantly inhibited $\mathrm{I}_{\mathrm{ANO} O}$ in a dose-dependent manner. TRPM7 currents were elicited by voltage ramps ranging from -100 to $+100 \mathrm{mV}$ from a holding potential of -60 $\mathrm{mV}$. After break-in, 2-3 min was allowed for current amplitudes to reach the steady state. The currents displayed a profound outwardly rectifying I-V relationship in $\mathrm{Ca}^{2+}$-containing normal bath solution (normal bath), presumably due to the relatively small inward current carried by $\mathrm{Ca}^{2+}$ compared to the large outward current carried by $\mathrm{Cs}^{+}[56,57]$. In order to investigate the regulatory effects of quercetin on TRPM7 currents, we applied quercetin at different concentrations. Application of quercetin $(100-300 \mu \mathrm{M})$ to HEK cells transfected with TRPM7 elicited a rapid decrease in outward and inward whole-cell currents (Figs. 9Aa, 9Ba and 9Ca). The time course of outward current is plotted at $+100 \mathrm{mV}$ and inward current at $-100 \mathrm{mV}$ for respective cells $(\mathrm{n}=7$; Figs. $9 \mathrm{Ab}, 9 \mathrm{Bb}$ and $9 \mathrm{Cb})$. These effects were 


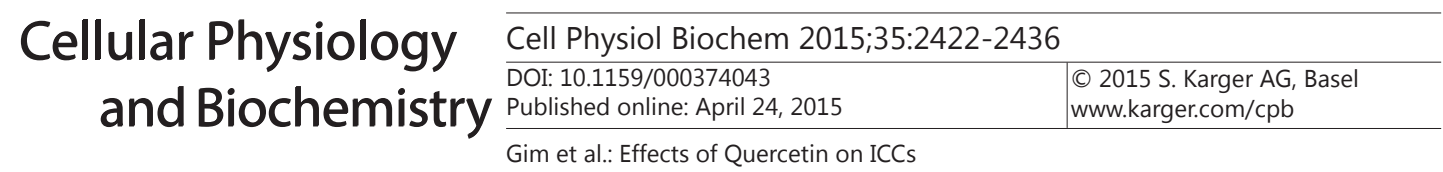

Fig. 10. Effects of quercetin on intestinal transit rate (ITR) in normal mice. The ITR (\%) values of Evans blue were measured $30 \mathrm{~min}$ after the p.o. administration of an Evans blue solution 30 min administering quercetin to normal mice. CTRL: Control. PF: Poncirus trifoliata Raf. i.g.: intragastrically. ${ }^{*} P<0.01$.

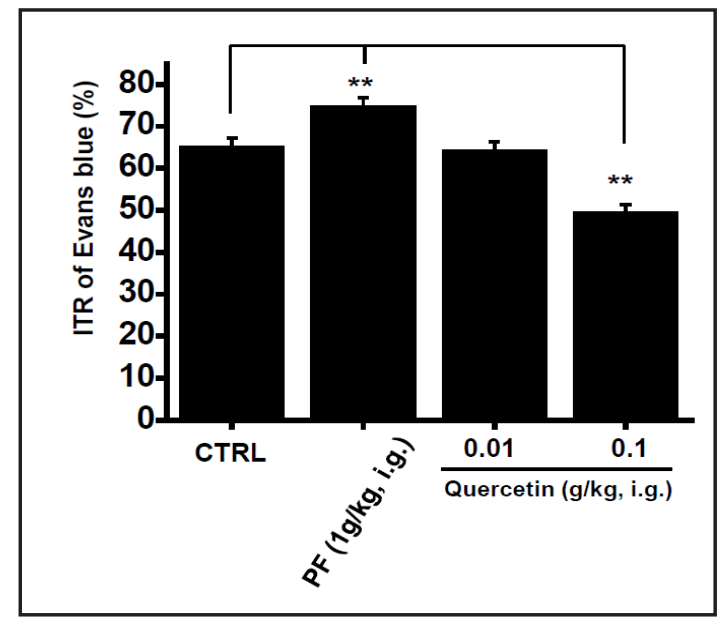

reproducible and fully reversible, and repeated application of quercetin yielded similar reductions in current amplitude. Mean peak inward and outward current densities before and after quercetin application were $-2.5 \pm 0.5 \mathrm{pA} / \mathrm{pF}$ and $-1.0 \pm 0.3 \mathrm{pA} / \mathrm{pF}$ at $-100 \mathrm{mV}$ and $+155.2 \pm 3.2 \mathrm{pA} / \mathrm{pF}$ and $+74.5 \pm 2.1 \mathrm{pA} / \mathrm{pF}$ at $+100 \mathrm{mV}$ for quercetin at $100 \mu \mathrm{M},-4.1 \pm 0.3$ $\mathrm{pA} / \mathrm{pF}$ and $-1.7 \pm 0.2 \mathrm{pA} / \mathrm{pF}$ at $-100 \mathrm{mV}$ and $+153.4 \pm 1.5 \mathrm{pA} / \mathrm{pF}$ and $+60.3 \pm 2.5 \mathrm{pA} / \mathrm{pF}$ at $+100 \mathrm{mV}$ for quercetin at $200 \mu \mathrm{M}$, and $-2.6 \pm 0.5 \mathrm{pA} / \mathrm{pF}$ and $-1.0 \pm 0.5 \mathrm{pA} / \mathrm{pF}$ at $-100 \mathrm{mV}$ and $+161.4 \pm 2.3 \mathrm{pA} / \mathrm{pF}$ and $+41.4 \pm 2.2 \mathrm{pA} / \mathrm{pF}$ at $+100 \mathrm{mV}$ for quercetin at $300 \mu \mathrm{M}$, respectively ( $\mathrm{n}=8$, mean \pm SEM; Fig. 9).

\section{Effects of quercetin on ITR in normal mice}

The ITRs (\%) of Evans blue over 30 min in normal mice are shown in Fig. 10. The ITR for untreated normal mice (control, $\mathrm{n}=25$ ) was $65.3 \pm 2.1 \%$. To examine GI motility regulation by quercetin, the aqueous extract of the dried immature fruits of Poncirus trifoliata Raf. (PF) was used. PF is one of the most popular traditional folk medicines in Korea as is derived from the Rutaceae fruits. It has been shown to have unique and potent prokinetic activities in normal rodents and in rodent models of GI motility dysfunction (GMD) [58, 59]. PF significantly increased ITR (\%) at a dose of $1 \mathrm{~g} / \mathrm{kg}$ (by $75.1 \pm 1.8 \%$, p<0.01), which is consistent with previous reports $[60,61]$. However, the ITR values for quercetin administered at 10 and 100 $\mathrm{mg} / \mathrm{kg}$ doses were $64.5 \pm 1.9$ and $49.8 \pm 1.7 \%$, respectively $(\mathrm{n}=10$; Fig. 10$)$, that is, quercetin reduced the ITR.

\section{Discussion}

In the present study, we found that quercetin decreased the amplitude and frequency of ICC pacemaker activity via a series of opioid receptor signaling pathways, including G protein-cGMP-PKG-NO activation. As ICC pacemaker activities are mainly due to periodic activations of TRPM7 channels [24, 33] or AN01 channels [35, 37, 38], TRPM7 and ANO1 modulators are potential targets for the treatment of GI motility disorders. In the present study, quercetin inhibited TRPM7 and ANO1 currents, indicating that the TRPM7 and ANO1 channels are involved in the quercetin-mediated inhibition of pacemaker activity in ICCs. In addition, in vivo, quercetin (10-100 $\mathrm{mg} / \mathrm{kg}$, p.o.) dose-dependently decreased ITR in normal mice.

With regard to intestinal motility, quercetin has been reported to inhibit the peristalsis of guinea pig ileum in vitro [62] and to depress intestinal motility in a concentrationdependent manner by facilitating inhibitory enteric pathways [63]. Furthermore, quercetin was found to be associated with decreases in some inflammation markers and changes in gut microbiota when administered to healthy mice [64]. In the present study, quercetin inhibited ICCs pacemaker activity and suppressed ITR in mice. 
In a previous study, we found that ANO1 was well expressed in ICCs within 12 hours of culture, but subsequently decreased with time [40]. Therefore, in the present study, we used ICCs that had been cultured for least than 12 hours (Fig. 1). Previous reports have shown TRPM7 and ANO1 mRNA are present and TRPM7 and ANO1 currents are expressed in cultured ICCs $[24,35,40,41]$, and thus, we examined the effects of quercetin on ANO1 and TRPM7 channels in HEK 293 cells, which overexpress both channels. Quercetin is the most abundant flavonoid and decreases the ICC pacemaker activity (Fig. 2) and induces G protein-cGMP-PKG-NO sensitive pacemaker potentials (Fig, 5 and 6). We are of the opinion that quercetin might decrease GI motility at the tissue level based on the observations that; 1) quercetin inhibited TRPM7 and ANO1 channels and 2) decreased the pacemaker activities of cluster type ICCs.

We believe that TRPM7 and AN01 are involved in the upstroke of pacemaker potentials. In ICCs, inhibitory neurotransmitters induce hyperpolarization and reduce the amplitude and frequency of pacemaker activity. In the present study, quercetin also reduced the amplitude and frequency of pacemaker activity. Therefore, we believe that quercetin may have the same functions as inhibitory neurotransmitter. Specific details of ion channel mechanisms during the upstroke and plateau phase of pacemaker potentials have not been elucidated. Therefore, it is difficult to determine with precision the effects of quercetin on pacemaker potentials, additional studies are required to identify the ion channels involved. In addition, we cannot explain the exact mechanism underlying the reduction of motility rate induced by quercetin. However, we suppose because quercetin inhibited TRPM7 and ANO1 channels and decreased pacemaker activity in cluster type ICCs that this inhibition might be due to inhibition of smooth muscle or the enteric nervous system.

In conclusion, we found that quercetin reduced the amplitude and frequency of ICC pacemaker activity in a G protein-, cGMP-, PKG-, and NO-dependent manner via opioid receptor activation. Furthermore, TRPM7 and ANO1 were found to be involved in the quercetin-induced regulation of pacemaker activity in cultured murine ICCs. Finally, our findings suggest that quercetin should be viewed as a novel drug development candidate for the treatment of GI spasm, pain, transit disturbances, and other symptoms related to GI motility disorders.

\section{Acknowledgements}

This work was supported by a National Research Foundation of Korea (NRF) Grant funded by the Korea government (MSIP) (\#2014R1A5A2009936).

\section{Disclosure Statement}

The authors have no potential conflict of interest to declare.

\section{References}

1 Hertog MG, Feskens EJ, Hollman PC, Katan MB, Kromhout D: Dietary antioxidant flavonoids and risk of coronary heart disease: the Zutphen Elderly Study. Lancet 1993;342:1007-1011.

2 Nijveldt RJ, van Nood E, van Hoorn DE, Boelens PG, van Norren K, van Leeuwen PA: Flavonoids: a review of probable mechanisms of action and potential applications. Am J Clin Nutr 2001;74:418-425.

3 Kahraman A, Erkasap N, Köken T, Serteser M, Aktepe F, Erkasap S: The antioxidative and antihistaminic properties of quercetin in ethanol-induced gastric lesions. Toxicology 2003;183:133-142.

4 Erlund I, Freese R, Marniemi J, Hakala P, Alfthan G: Bioavailability of quercetin from berries and the diet. Nutr Cancer 2006;54:13-17. 


\section{Cellular Physiology Cell Physiol Biochem 2015;35:2422-2436

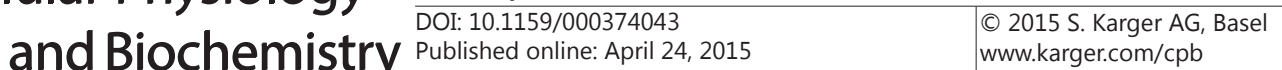 \\ Gim et al.: Effects of Quercetin on ICCS}

5 Mann GE, Rowlands DJ, Li FY, de Winter P, Siow RC: Activation of endothelial nitric oxide synthase by dietary isoflavones: role of NO in Nrf2-mediated antioxidant gene expression. Cardiovasc Res 2007;75:261-274.

6 Ertug PU, Aydinoglu F, Goruroglu Ozturk O, Singirik E, Ogulener N: Comparative study of the quercetin, ascorbic acid, glutathione and superoxide dismutase for nitric oxide protecting effects in mouse gastric fundus. Eur J Pharmacol 2013;698:379-387.

7 Lopez-Lopez G,Moreno L, Cogolludo A, Galisteo M, Ibarra M, Duarte J, Lodi F, Tamargo J, Perez-Vizcaino F: Nitric oxide (NO) scavenging and NO protecting effects of quercetin and their biological significance in vascular smooth muscle. Mol Pharmacol 2004;65:851-859.

8 Mahmoud MF, Hassan NA, El Bassossy HM, Fahmy A: Quercetin protects against diabetes-induced exaggerated vasoconstriction in rats: effect on low grade inflammation. PLoS One 2013;8:e63784.

9 Crowe FL, Crowe FL, Roddam AW, Key TJ, Appleby PN, Overvad K, Jakobsen MU, Tjønneland A, Hansen L, Boeing H, Weikert C, Linseisen J, Kaaks R, Trichopoulou A, Misirli G, Lagiou P, Sacerdote C, Pala V, Palli D, Tumino R, Panico S, Bueno-de-Mesquita HB, Boer J, Gils CH, Beulens JW, Barricarte A, Rodríguez L, Larrañaga N, Sánchez MJ, Tormo MJ, Buckland G, Lund E, Hedblad B, Melander O, Jansson JH, Wennberg P, Wareham NJ, Slimani N, Romieu I, Jenab M, Danesh J, Gallo V, Norat T, Riboli E: Fruit and vegetable intake and mortality from ischaemic heart disease: results from the European Prospective Investigation into Cancer and Nutrition (EPIC)-Heart study. Eur Heart J 2011;32:1235-1243.

10 Vasanthi HR, ShriShriMal N, Das DK: Phytochemicals from plants to combat cardiovascular disease. Curr Med Chem 2012;19:2242-2251.

11 Pignatelli P, Pulcinelli FM, Celestini A, Lenti L, Ghiselli A, Gazzaniga PP, Violi F: The flavonoids quercetin and catechin synergistically inhibit platelet function by antagonizing the intracellular production of hydrogen peroxide. Am J Clin Nutr 2000;72:1150-1155.

12 Das DK, Chakraborty A, Sinha M, Manna K, Mukherjee D, Chakraborty A, Bhattacharjee S, Dey S: Modulatory role of quercetin against gamma radiation-mediated biochemical and morphological alterations of red blood cells. Int J Radiat Biol 2013;89:471-481.

13 Liu CJ, Lin JY: Anti-inflammatory effects of phenolic extracts from strawberry and mulberry fruits on cytokine secretion profiles using mouse primary splenocytes and peritoneal macrophages. Int Immunopharmacol 2013;16:165-170.

14 Bardy G, Virsolvy A, Quignard JF, Ravier MA, Bertrand G, Dalle S, Cros G, Magous R, Richard S, Oiry C: Quercetin induces insulin secretion by direct activation of L-type calcium channels in pancreatic beta cells. Br J Pharmacol 2013;169:1102-1113.

15 Kim MC, Lee HJ, Lim B, Ha KT, Kim SY, So I, Kim BJ: Quercetin induces apoptosis by inhibiting MAPKs and TRPM7 channels in AGS cells. Int J Mol Med 2014;33:1657-1663.

16 Moon J, Lee SM, Do HJ, Cho Y, Chung JH, Shin MJ: Quercetin up-regulates LDL receptor expression in HepG2 cells. Phytother Res 2012;26:1688-1694.

17 Shen Y, Ward NC, Hodgson JM, Puddey IB, Wang Y, Zhang D, Maghzal GJ, Stocker R, Croft KD: Dietary quercetin attenuates oxidant-induced endothelial dysfunction and atherosclerosis in apolipoprotein $\mathrm{E}$ knockout mice fed a high-fat diet: a critical role for heme oxygenase-1. Free Radic Biol Med 2013;65:908915.

18 Kressler J, Millard-Stafford M, Warren GL: Quercetin and endurance exercise capacity: a systematic review and meta-analysis. Med Sci Sports Exerc 2011;43:2396-2404.

19 Di Carlo G, Mascolo N, Izzo AA, Capasso F: Effects of quercetin on the gastrointestinal tract in rats and mice. Phytother Res 1994;8:42-45.

20 Hammad HM, Abdalla SS: Pharmacological effects of selected flavonoids on rat isolated ileum: Structureactivity relationship. Gen Pharmacol 1997;28:767-771.

21 Galvez J, Crespo ME, Jimenez J, Suarez A, Zarzuelo A: Antidiarrhoeic activity of quercitrin in mice and rats. J Pharm Pharmacol 1993;45:157-159.

22 Huizinga JD, Thuneberg L, Kluppel M, Malysz J, Mikkelsen HB, Bernstein A: W/kit gene required for interstitial cells of Cajal and for intestinal pacemaker activity. Nature 1995;373:347-349.

23 Sanders KM: A case for interstitial cells of Cajal as pacemakers and mediators of neurotransmission in the gastrointestinal tract. Gastroenterology 1996;111:492-515. 


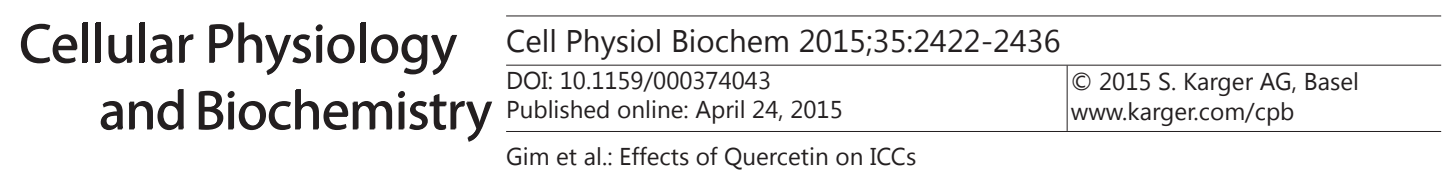

24 Kim BJ, Lim HH, Yang DK, Jun JY, Chang IY, Park CS, So I, Stanfield PR, Kim KW: Melastatin-Type Transient Receptor Potential Channel 7 Is Required for Intestinal Pacemaking Activity. Gastroenterology 2005;129:1504-1517.

25 Berezin I, Huizinga JD, Farraway L, Daniel EE: Innervation of interstitial cells of Cajal by vasoactive intestinal polypeptide containing nerves in canine colon. Can J Physiol Pharmacol 1990;68:922-932.

26 Nam JH, Kim WK, Kim BJ: Sphingosine and FTY720 modulate pacemaking activity in interstitial cells of Cajal from mouse small intestine. Mol Cells 2013;36:235-244.

27 Ward SM, Beckertt EA, Wang X, Baker F, Khoyi M, Sanders KM: Interstitial cells of Cajal mediate cholinergic neurotransmission from enteric motorneurons. J Neurosci 2000;20:1393-1403.

28 Lee JH, Kim SY, Kwon YK, Kim BJ, So I: Characteristics of the cholecystokinin-induced depolarization of pacemaking activity in cultured interstitial cells of Cajal from murine small intestine. Cell Physiol Biochem. 2013;31:542-554.

29 Kim BJ, Kim SY, Lee S, Jeon JH, Matsui H, Kwon YK, Kim SJ, So I: The role of transient receptor potential channel blockers in human gastric cancer cell viability. Can J Physiol Pharmacol 2012;90:175-186.

30 Hwang MW, Kim JN, Song HJ, Lim B, Kwon YK, Kim BJ: Effects of Lizhong Tang on cultured mouse small intestine interstitial cells of Cajal. World J Gastroenterol 2013;19:2249-2255.

31 Kim BJ, Kim HW, Lee GS, Choi S, Jun JY, So I, Kim SJ: Poncirus trifoliate fruit modulates pacemaker activity in interstitial cells of Cajal from the murine small intestine. J Ethnopharmacol 2013;149:668-675.

32 Koh SD, Jun JY, Kim TW, Sanders KM: A Ca2+-inhibited non-selective cation conductance contributes to pacemaker currents in mouse interstitial cell of Cajal. J Physiol 2002;540:803-814.

33 Kim BJ, So I, Kim KW: The relationship of TRP channels to the pacemaker activity of interstitial cells of Cajal in the gastrointestinal tract. J Smooth Muscle Res 2006;42:1-7.

34 Huizinga JD, Zhu Y, Ye J, Molleman A: High conductance chloride channels generate pacemaker currents in interstitial cells of Cajal. Gastroenterology 2002;123:1627-1636.

35 Zhu MH, Kim TW, Ro S, Yan W, Ward SM, Koh SD, Sanders KM: A Ca2+-activated Cl-conductance in interstitial cells of Cajal linked to slow wave currents and pacemaker activity. J Physiol 2009;587:49054918.

36 Zhu Y, Mucci A, Huizinga JD: Inwardly rectifying chloride channel activity in intestinal pacemaker cells. Am J Physiol Gastrointest Liver Physiol 2005;288:G809-821.

37 Huang F, Rock JR, Harfe BD, Cheng T, Huang X, Jan YN, Jan LY: Studies on expression and function of the TMEM16A calcium-activated chloride channel. Proc Natl Acad Sci U S A 2009;106:21413-21418.

38 Namkung W, Yao Z, Finkbeiner WE, Verkman AS: Small-molecule activators of TMEM16A, a calciumactivated chloride channel, stimulate epithelial chloride secretion and intestinal contraction. FASEB J 2011;25:4048-4062.

39 Sanders KM, Zhu MH, Britton F, Koh SD, Ward SM: Anoctamins and gastrointestinal smooth muscle excitability. Exp Physiol. 2012;97:200-206.

40 Kim BJ, Nam JH, Kim KH, Joo M, Ha TS, Weon KY, Choi S, Jun JY, Park EJ, Wie J, So I, Nah SY: Characteristics of gintonin-mediated membrane depolarization of pacemaker activity in cultured interstitial cells of Cajal. Cell Physiol Biochem. 2014;34:873-890.

41 Shahi PK, Choi S, Zuo DC, Kim MY, Park CG, Kim YD, Lee J, Park KJ, So I, Jun JY: The possible roles of hyperpolarization-activated cyclic nucleotide channels in regulating pacemaker activity in colonic interstitial cells of Cajal. J Gastroenterol 2014;49:1001-1010.

42 Scott RB, Tan DT: Mediation of altered motility in food protein induced intestinal anaphylaxis in HoodedLister rat. Can J Physiol Pharmacol. 1996;74:320-330.

43 Salah AM, Gathumbi J, Vierling W: Inhibition of intestinal motility by methanol extracts of Hibiscus sabdariffa L. (Malvaceae) in rats. Phytother Res 2002;16:283-285.

44 Gharzouli K, Holzer P: Inhibition of guinea pig intestinal peristalsis by the flavonoids quercetin, naringenin, apigenin and genistein. Pharmacology 2004;70:5-14.

45 Baggio CH, Freitas CS, Mayer B, Dos Santos AC, Twardowschy A, Potrich FB, Cipriani TR, de Souza LM, Sassaki GL, Iacomini M, Marques MC, Mesia-Vela S: Muscarinic-dependent inhibition of gastric emptying and intestinal motility by fractions of Maytenus ilicifolia Mart ex. Reissek. J Ethnopharmacol 2009;123:385391. 


\section{Cellular Physiology Cell Physiol Biochem 2015;35:2422-2436 \begin{tabular}{l|l|l} 
and Biochemistry & $\begin{array}{l}\text { DOI. 10.1159/000374043 } \\
\text { Published online: April 24, 2015 }\end{array}$ & $\begin{array}{l}\text { O) 2015 S. Karger AG, Basel } \\
\text { www.karger.com/cpb }\end{array}$ \\
\cline { 2 - 3 }
\end{tabular} \\ Gim et al.: Effects of Quercetin on ICCs}

46 Kahle K, Kempf M, Schreier P, Scheppach W, Schrenk D, Kautenburger T, Hecker D, Huemmer W, Ackermann M, Richling E: Intestinal transit and systemic metabolism of apple polyphenols. Eur J Nutr 2011;50:507522.

47 Foss JF: A review of the potential role of methylnaltrexone in opioid bowel dysfunction. Am J Surg 2001;182:19S-26S.

48 Anselmi L, Huynh J, Vegezzi G, Sternini C: Effects of methylnaltrexone on guinea pig gastrointestinal motility. Naunyn Schmiedebergs Arch Pharmacol 2013;386:279-286.

49 Gharzouli K, Holzer P: Inhibition of guinea pig intestinal peristalsis by the flavonoids quercetin, naringenin, apigenin and genistein. Pharmacology 2004;70:5-14.

50 Bagnol D, Mansour A, Akil H, Watson SJ: Cellular localization and distribution of the cloned mu and kappa opioid receptors in rat gastrointestinal tract. Neuroscience 1997;81:579-591.

51 Culpepper-Morgan JA, Inturrisi CE, Portenoy RK, Foley K, Houde RW, Marsh F, Kreek MJ: Treatment of opioid-induced constipation with oral naloxone: a pilot study. Clin Pharmacol Ther 1992;52:90-95.

52 Yuan CS, Foss JF, Moss J: Effects of methylnaltrexone on morphine-induced inhibition of contraction in isolated guinea pig ileum and human intestine. Eur J Pharmacol 1995;276:107-111.

53 Komori S, Kawai M, Takewaki T, Ohashi H. GTP-binding protein involvement in membrane currents evoked by carbachol and histamine in guinea-pig ileal muscle. J Physiol 1992;450:105-126.

54 Ogata R, Inoue Y, Nakano H, Ito Y, Kitamura K. Oestradiol-induced relaxation of rabbit basilar artery by inhibition of voltage-dependent Ca channels through GTP-binding protein. Br J Pharmacol 1996;117:351359.

55 Moncada S, Palmer RMJ, Higgs EA: Nitric oxide: physiology, pathophysiology, and pharmacology. Pharmacol Rev 1991;43:109-142.

56 Nadler MJS, Hermosura MC, Inabe K, Perraud AL, Zhu Q Stokes AJ, Kurosaki T, Kinet JP, Penner R, Scharenberg AM, Fleig A: LTRPC7 is a MgNATP-regulated divalent cation channel required for cell viability. Nature 2001;411:590-595.

57 Runnels LW, Yue L, Clapham DE: The TRPM7 channel is inactivated by PIP(2) hydrolysis. Nat Cell Biol 2002;4:329-336.

58 Kim BJ, Kim HW, Lee GS, Choi S, Jun JY, So I, Kim SJ: Poncirus trifoliate fruit modulates pacemaker activity in interstitial cells of Cajal from the murine small intestine. J Ethnopharmacol 2013;149:668-675.

59 Lyu JH, Lee HT: Effects of dried Citrus unshiu peels on gastrointestinal motility in rodents. Arch Pharm Res 2013;36:641-648.

60 Lee HT, Seo EK, Chung SJ, Shim CK: Prokinetic activity of an aqueous extract from dried immature fruit of Poncirus trifoliata (L.) Raf. J Ethnopharmacol 2005;102:131-136.

61 Lee HT, Seo EK, Chung SJ, Shim CK: Effect of an aqueous extract of dried immature fruit of Poncirus trifoliata (L.) Raf. J Ethnopharmacol 2005;102:302-306.

62 Lozoya X, Meckes M, Abou-Zaid M, Tortoriello J, Nozzolillo C, Arnason JT: Quercetin glycosides in Psidium guajava L. leaves and determination of a spasmolytic principle. Arch Med Res 1994;25:11-5.

63 Gharzouli K, Holzer P: Inhibition of guinea pig intestinal peristalsis by the flavonoids quercetin, naringenin, apigenin and genistein. Pharmacology. 2004;70:5-14.

64 Espley RV, Butts CA, Laing WA, Martell S, Smith H, McGhie TK, Zhang J, Paturi G, Hedderley D, Bovy A, Schouten HJ, Putterill J, Allan AC, Hellens RP: Dietary flavonoids from modified apple reduce inflammation markers and modulate gut microbiota in mice. J Nutr 2014;144:146-154. 